\title{
OBSERVATION OF DYSTOCIA IN WILD ELK
}

\author{
Chad P. Lehman ${ }^{1}$, Lowell E. Schmitz ${ }^{2}$, Mark A. Rumble ${ }^{3}$, Jackie J. Kragel ${ }^{4}$, and Joshua J. Millspaugh ${ }^{5}$
}

ABSTRACT.-On the basis of reports in the literature, incidence of dystocia in wild elk (Cervus elaphus) across the west is rare. In 2011, one of $34(3 \%)$ pregnant cow elk in our study experienced dystocia during birth. Our visual observations indicated that it took approximately 4 days for a radio-collared cow elk to succumb to dystocia in our study. Little is known about dystocia in wild elk populations, and our observation provides some insight about fetal malpresentations.

\footnotetext{
RESUMEN.-Con base en los reportes en la literatura, en el occidente no es muy frecuente la incidencia de distocia en el ciervo rojo (Cervus elaphus). En 2011, 1 de cada 34 (3\%) hembras preñadas en nuestro estudio experimentó distocia al momento de parir. Nuestras observaciones visuales indican que durante nuestro estudio pasaron aproximadamente 4 días para que una hembra preñada con un collar de telemetría sucumbiera a la distocia. Se conoce muy poco sobre la distocia en las poblaciones de ciervos rojos, y nuestra observación proporciona información sobre la mala presentación fetal.
}

We report on an observation of dystocia in a wild elk (Cervus elaphus) which was radiomarked in the Black Hills, South Dakota. Dystocia is defined as a difficult parturition (Sloss and Dufty 1980). Dystocia may cause death in both the mother and offspring, and mortalities from dystocia have been documented for wild caribou (Rangifer tarandus; Bergerud 1971), pronghorn (Antilocapra americana; Jacques et al. 2007), elk (Larkin et al. 2003), moose (Alces alces; Testa 2004), and musk oxen (Ovibos moschatus; Norment 1980). On 27 May 2011, we tracked a radio-marked cow elk after the vaginal implant transmitter had been activated following parturition. We visually observed the lone cow elk bedded on her side exhibiting calving behavior typical of second-stage laborears held back and mouth open during contractions (Hudson et al. 2002). We watched the female experience many contractions over a 45-min period, but neither the amniotic sac, nor the calf appeared, and we quietly left the site. We observed the radio-marked cow elk again on 28 May 2011 and noted that her vaginal opening was distended and swollen and that she appeared lethargic. We collected daily location coordinates of the cow elk and she was visually confirmed to be alive on 30 May. However, on 31 May, the cow elk was found dead on her side with all 4 legs extended approximately $800 \mathrm{~m}$ from the visual location obtained on 28 May. A field necropsy showed a fully developed female calf lodged in the birth canal. The fetus appeared recently dead with no sign of decomposition. Also, the cow elk exhibited little rigamortis of the leg muscles and most likely died in the early morning hours. Postmortem examination revealed the calf had an abnormal presentation and was posterior with the hind legs leading into the birth canal. The calf's hind legs were crossed, and the left tibia and metatarsus were bent around the right leg and stuck in the cervix. The bent-leg position of the left hind leg appeared to prevent passage through the pelvic girdle. Severe dystocia in cows occurs with the posterior presentation if the hind legs are flexed beneath the fetal body (Arthur 1975). The cow was lactating, and the rumen was approximately half full. The cow's estimated age was 6 years based on cementum annuli from an upper canine tooth (Hamlin et al. 2000). It took approximately 4 days for the radio-collared cow elk to succumb to dystocia. We report that 1 of $34(3 \%)$ pregnant cow elk experienced dystocia during birth for one year of data collection in 2011. Dystocia was reported in wild elk once previously (Larkin et

\footnotetext{
${ }^{1}$ South Dakota Department of Game, Fish and Parks, Custer State Park, 13329 U.S. Hwy. 16A, Custer, SD 57730. E-mail: chad.lehman@state.sd.us

${ }^{2}$ South Dakota Department of Game, Fish and Parks, The Outdoor Campus-West, 4130 Adventure Trail, Rapid City, SD 57702.

${ }^{3}$ USDA Forest Service, Rocky Mountain Research Station, 8221 South Hwy. 16, Rapid City, SD 57702.

${ }^{4}$ South Dakota Department of Game, Fish and Parks, 13329 US. Hwy. 16A, Custer, SD 57730.

${ }^{5}$ University of Missouri, Department of Fisheries and Wildlife Sciences, 302 Anheuser-Busch Natural Resources Building, Columbia, MO 65211.
} 
al. 2003). The authors noted its occurrence but did not provide specific details. Dystocia can occur at a high rate in farmed elk (Freidel and Hudson 1994, Pople et al. 2001) and can be an important cause of mortality and economic loss for producers (Pople et al. 2001). A comprehensive survey of North American elk farm producers indicated dystocia occurred in 5.9\% of births (Woodbury et al. 2006). Little is known about dystocia in wild elk populations, and most likely fetal malpresentations do not occur often. Research with objectives specific to elk reproduction would provide additional insight into dystocia in wild elk.

We thank S. Lindsay, DVM, for constructive comments and additions to this manuscript. Funding for this research was from the South Dakota Department of Game, Fish and Parks, Federal Aid to Wildlife Restoration Fund (Project W-75-R-53, No. 7544), and the Rocky Mountain Elk Foundation. Additional field assistance and technical support was provided by the USDA Forest Service, Rocky Mountain Research Station. Technical support was provided by the University of Missouri-Columbia. All handling, marking, and monitoring procedures were approved by the South Dakota State University Research Committee (Institutional Animal Care and Use Committee Approval Number 11-012A).

\section{Literature Cited}

ARTHUR, G.H. 1975. Veterinary reproduction and obstetrics. 4th edition. Williams and Wilkins, Baltimore, MD.
Bergerud, A.T. 1971. The population dynamics of Newfoundland caribou. Wildlife Monographs 25:3-55.

Friedel, B.A., AND R.J. Hudson. 1994. Productivity of farmed wapiti in Alberta. Canadian Journal of Animal Science 74:297-303.

Hamlin, K.L., D.F. PaC, C.A. Sime, R.M. Desimone, and G.L. DuseK. 2000. Evaluating the accuracy of ages obtained by two methods for montane ungulates. Journal of Wildlife Management 64:441-449.

Hudson, R.J., J.C. Haigh, and A.B. Bubenik. 2002. Pages 199-257 in D.E. Toweill and J.W. Thomas, editors, Physical and physiological adaptations: North American elk ecology and management. Wildlife Management Institute, Washington, DC.

JacQues, C.N., J.A. Jenks, J.D. Sievers, D.E. Roddy, And F.G. LinDZEY. 2007. Survival of pronghorns in western South Dakota. Journal of Wildlife Management 71:737-743.

Larkin, J.L., D.S. Maehr, J.J. Cox, D.C. Bolin, and M.W. WICHROWSKI. 2003. Demographic characteristics of a reintroduced elk population in Kentucky. Journal of Wildlife Management 67:467-476.

NoRmENT, C.J. 1980. Breech presentation of the fetus in a pregnant muskox. Journal of Mammalogy 61:776-777.

Pople, N.C., A.L. Allen, AND M.R. Woodbury. 2001. A retrospective study of neonatal mortality in farmed elk. Canadian Veterinarian Journal 42:925-928.

Sloss, V., and J.H. DufTy. 1980. Handbook of bovine obstetrics. 2nd edition. Williams and Wilkins Company, Baltimore, MD.

Testa, J.W. 2004. Source population dynamics and life history trade-offs of moose (Alces alces) in southcentral Alaska. Ecology 85:1439-1452.

Woodbury, R.M., J. Berezowski, And J. Haigh. 2006. An estimation of reproductive performance of farmed elk (Cervus elaphs) in North America. Canadian Veterinarian Journal 47:60-64.

Received 23 November 2011 Accepted 13 February 2012 